\title{
Gabriella Farina, Benjamin Fondane e le gouffre. Un emigrante nella metafisica dell'esistenza
}

\section{Emanuele Kanceff}

\section{(2) OpenEdition}

\section{Journals}

Edizione digitale

URL: https://journals.openedition.org/studifrancesi/38283

DOI: 10.4000/studifrancesi.38283

ISSN: 2421-5856

Editore

Rosenberg \& Sellier

\section{Edizione cartacea}

Data di pubblicazione: 15 décembre 2004

Paginazione: 648

ISSN: 0039-2944

\section{Notizia bibliografica digitale}

Emanuele Kanceff, «Gabriella Farina, Benjamin Fondane e le gouffre. Un emigrante nella metafisica dell'esistenza», Studi Francesi [Online], 144 (XLVIII | III) | 2004, online dal 30 novembre 2015, consultato il 08 mai 2021. URL: http://journals.openedition.org/studifrancesi/38283 ; DOI: https://doi.org/ 10.4000/studifrancesi.38283

Questo documento è stato generato automaticamente il 8 mai 2021.

\section{(c) $(1)$}

Studi Francesi è distribuita con Licenza Creative Commons Attribuzione - Non commerciale - Non opere derivate 4.0 Internazionale. 


\title{
Gabriella Farina, Benjamin Fondane e le gouffre. Un emigrante nella metafisica dell'esistenza
}

\author{
Emanuele Kanceff
}

\section{NOTIZIA}

GABRIELLA FARINA, Benjamin Fondane e le gouffre. Un emigrante nella metafisica dell'esistenza, Roma, Artemide Edizioni, 2003 (Coll. "Proteo”, 16), pp. 127.

1 Come scrive Monique Jutrin nella sua biografia, «filosofo, poeta, critico letterario, traduttore, saggista, sceneggiatore e uomo di teatro, Benjamin Fondane nasce il 14 novembre 1898 a Jassy in Moldavia, in una famiglia di intellettuali ebrei, con un altro nome, quello di Benjamin Wechsler, divenendo per uno strano e misterioso destino il simbolo vivente di una vita errante che gli ha conferito la parte di viaggiatore senza meta e senza porti di approdo».

2 Fin dalla densa introduzione si rivela la complessa operazione che l'A. si propone: presentare Fondane superando la difficoltà del suo duplice essere poeta e filosofo. I primi anni di attività, dalle avanguardie alla fisolofia dell'esistenza, costituiscono appunto la materia del primo capitolo, seguito da un'altra riflessione su "emigranti, diamanti della terra" e dall'esposizione della "metafisica del gouffre". È poi la volta di "Rimbaud le voyou" e di "Baudelaire e l'esperienza del gouffre". La filosofia della tragedia; L'esistenza concreta; Il grido della coscienza infelice rappresentano la più matura riflessione, sino ai riflessi intorno a Nietzsche, Kierkegaard e l'abisso della disperazione, Sestov e la metafisica "ai confini del reale". Una bella visione metaforica chiude il volume con Il Lunedì dell'esistenza e la Domenica della storia. 